\title{
Editorial
}

\section{Beyond capitalism and socialism: Human manifesto}

Members of our generation are fortunate to participate in one of the greatest transformations in the history of socio-economic systems: from the exhausted and spent corso of the division of labor and knowledge to the strength-gathering ricorso of their subsequent and inevitable reintegration and reaggregation.

Socio-economic and political orders are being profoundly affected by the reintegrative ricorso now taking place: both in socialism and capitalism, prevailing trends point towards new systems of participative autonomy or social participation. There is no other way, no 'third way', and no el otro sandero: the process itself is spontaneous, unavoidable and beyond the manipulations of tired and increasingly irrelevant social engineers and planners.

There are only two human systems principles worthy of serious attention in the 'knowledge era':

(1) To achieve optimal utilization, 'land should belong to those who work it'. In other words, to assure their optimal utilization, productive resources (farms, factories, enterprises, institutions and other means of production or service) should be jointly share-owned by their employees.

(2) Larger contribution to such jointly owned system should be rewarded more and smaller contribution less. Systems deviating from this simple principle are exploitative of both nature and humanity and doomed to vanish when exposed to competition.

Both of these principles are definitionally violated under socialism while the first principle still remains violated under capitalism.

North-Holland

Human Systems Management 7 (1988) 185-188
In both systems the main problem is the gap between ownership and employment (or management). The size of this gap is an approximate measure of system's deviation from its optimal social pattern. Ideally, owners should be the employees and employees should be the owners - all to different degrees of their differential contributions. (Securing the minimum standard for those who simply cannot contribute more is a dependent problem which can be effectively solved only in an optimally productive system.)

Modern capitalism is based on the separation of absentee owners and non-owning employees (workers and managers). While absentee owners can acquire and dispose of their stock within seconds, and thus their interests are necessarily symbolic (monetary) and short-term, the employees cannot exercise their real and long-term interests because they are not the owners.

Socialism has recognized the ownership-employment gap but aggravated it, tragically and paradoxically, even further: by transferring the ownership from absentee owners to the state. State 'ownership' is the most artificial and anonymous form of ownership 'by all' or 'by the society': i.e., by nobody. What belongs to all cannot belong to anybody; the social responsibility and motivation are thus effectively destroyed.

Socialism has never solved the crucial problem of who is going to stay overnight with a sick cow. Capitalism can solve it elegantly and efficiently: he, who owns the cow. At this stage, the absentee owner can at least contract somebody else to stay up: responsibility exists, but it is inefficiently exercised.

Why has Karl Marx not completed his mental experiment and proposed the transfer of the means of production from the absentee owners all the way to farmers, workers and employees, choosing instead to leave them 'hanging' in the hands of 
remote and anonymous state? We may never know.

It is becoming increasingly self-evident that the Society, the Nature itself, is going to complete this unfinished experiment.

There is nothing in socialist state ownership that would indicate a hint or promise of the desirable labor and knowledge reintegration. In fact, socialist state, if anything, perpetuates and aggravates the parasitic division of labor, specialization and atomization even more vigorously, and by administrative means and decrees on top of it.

The work under socialism becomes even less 'individual', workers become even more glaringly 'appendages' to machines and bureaucracies, and the 'army-like' organization of both enterprises and national economies is for 70 years allowed to celebrate its dogmatic heydays. All this flies directly in the face of Karl Marx's historical diagnosis.

Neither capitalism nor socialism imply labor and knowledge reintegration per se. This desirable transition is dependent on the ricorso stage of the economy, which is in turn dependent on the level and nature of technology and knowledge in the society. No reintegration can be simply declared or 'revolutionized' by the State before its time has come. The nature of social systems has little to do with state-declared 'glasnost', and everything to do with recognizing the right form of ownership-employment relationship: no separation of owners from employees.

Modern capitalism is also plagued by atomized and highly specialized partial employees, large and incompetent coordinative management hierarchies, separation of management and ownership (external absentee shareholders), short-term view of the enterprise and increasingly frightening decoupling and noncorrespondence of real and symbolic economies.

Reintegration of labor and knowledge, via automation and computerization, naturally reduces the scope and span of the inter- and intra-company command economy: fewer and fewer people are directly involved and can be directly commanded by the state or executive hierarchy. That's the hope that we share.

In fig. 1 we sketch the differences in embedding of the corporate micro-organization in a nationstate macro-system under both systemic arrangements. The difference lies at the macro-level: under socialism, all economy is organized as a

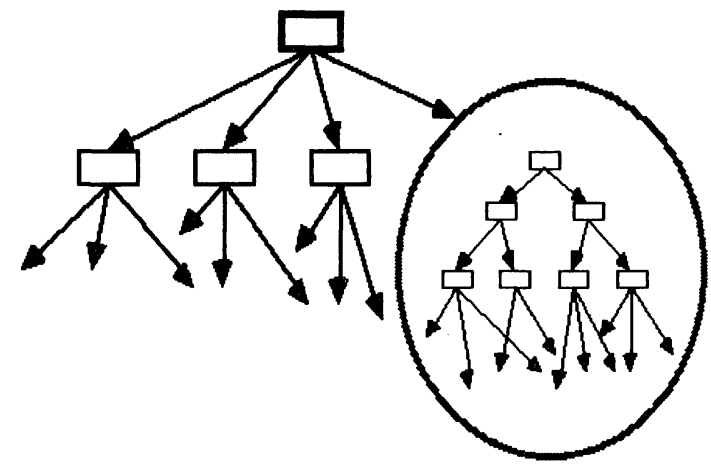

Socialism: both macro-and micro-systems are organized according to hierarchical principles of planning, decision making and cammand.

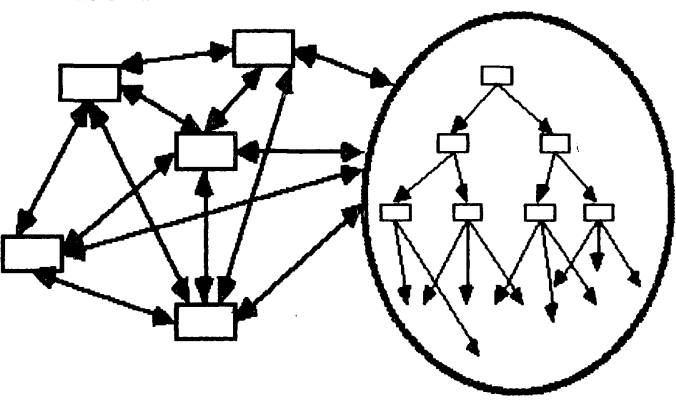

Capitalism: macro-system is organized according to self-organizing principles of the free market; while micro-systems (companies) according to fierarchical principles of planning, decision making and command.

Fig. 1.

hierarchical, planned, military-like company; under capitalism, outside the company, large portions of the economy remain free markets, open to fluctuations, capable of self-organization and self-coordination. This promotes entrepreneurship, adaptability and innovation, i.e., dimensions which cannot exist under bureaucratic socialism (or even under overbureaucratized state capitalism).

The newly emerging social system of participative autonomy will require appropriate conception of the 'free-market economy' also within the enterprise. In other words, we could be finally approaching the requisite harmony between the macro- and micro-organization of the society.

The system of participative autonomy is characterized by participatory democracy in the political sphere and partnership, autonomy and comanagement in the economic sphere.

As reintegration of labor and knowledge progress further, management, responsibilities and decision making functions start shifting to lower 
and lower levels of the already flattening hierarchies of coordination. Self-coordinating, decentralized systems require less of the centralized coordination, more of mutual adaptation. In order to assume the newly implied responsibility and decision-making power, the self-coordinating agents ( managers $=$ workers, producers = consumers) can gain their necessary motivation only from the direct ownership of the means of production.

In fig. 2 we outline an explanation of why can the system of intra-company command hierarchy persist even in the essentially free market environment: the culprit is the impermeable system boundary. Internal groups and individuals are shielded and sheltered from the market fluctuations and perturbations by a system of institutional points of contact, informational filters and 'environmental scanning' artifacts. Fluctuations

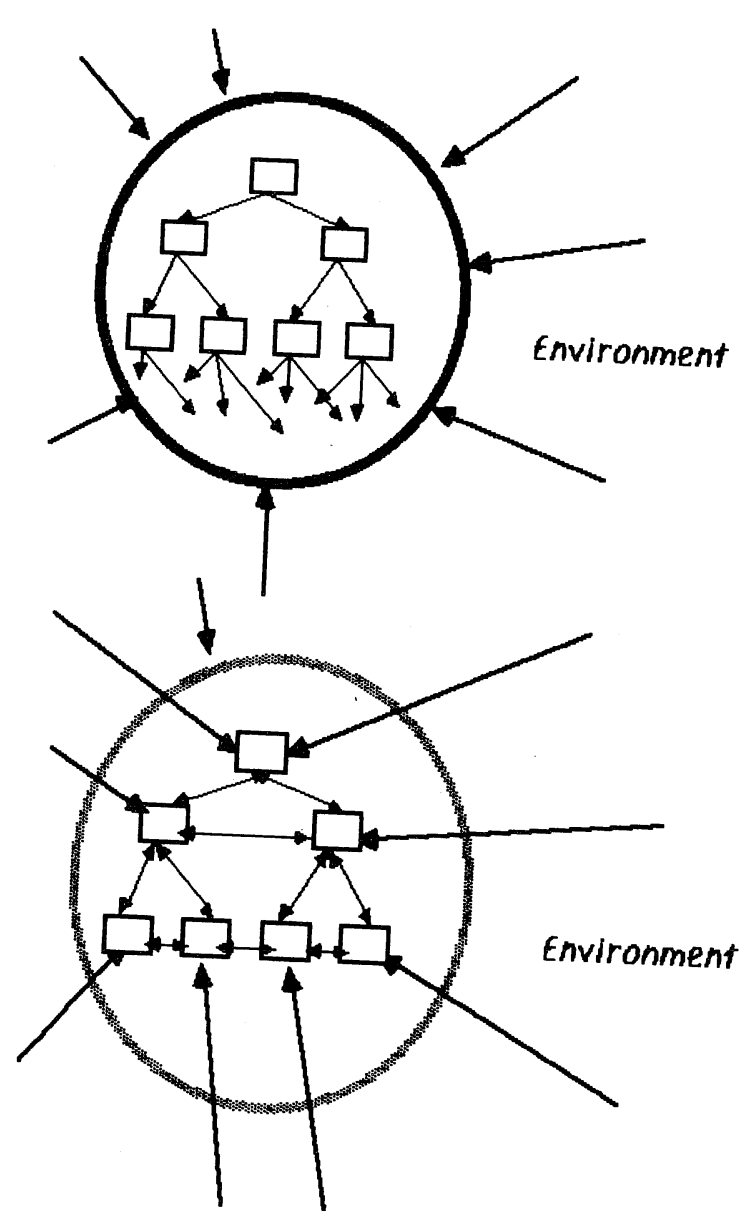

Fig. 2. cannot propagate throughout the organization, only rules, commands and questionnaires can. That prevents any self-organizing and self-managing phenomena to take place, either spontaneously or just-in-time.

Once we break down the censure of the artificial information membrane, and make it at least a semi-permeable one, environmental perturbations, fluctuations and 'in-formations' will not only get through, but shall reach their proper targets: individuals and groups down there, 'on the spot'. Such propagation of fluctuations throughout the organization is necessary for self-organization: it increases flexibility, stimulates formation of 'internal markets' and enhances self-coordinating and self-managing phenomena in a spontaneous and natural fashion.

Employees (workers and managers) must become direct (internal) shareholders and co-owners of the enterprise they participate in. Otherwise their outlook will be only short-term: inevitably they start preferring mindless commands from above to their own responsibility and participation. Separation of ownership and management, while useful and functional when dealing with manual labor, becomes an inefficient hindrance when dealing with knowledge, our newly emerged dominant form of 'capital'. Knowledge is different from labor and a whole new 'economics' must be created to take that fact into account.

Modern capitalism is making its transition spontaneously and naturally: through entering the ricorso stage and relying on the labor/knowledge reintegration as means of maintaining its strategic position, remaining competitive and surviving

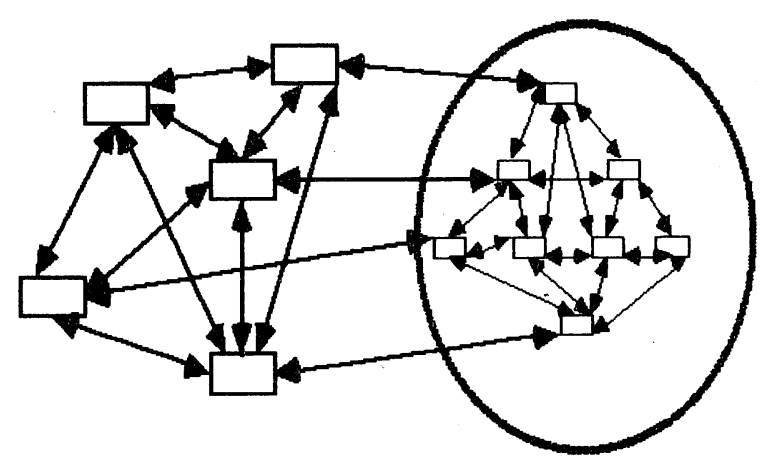

Social participation: both macro- and micro-systems are organized according to self-organizing external or internal market autanomy, self-management and co-determination.

Fig. 3. 
within the reduced niches of its increasingly threatened business ecology. Phenomena of multifunctionality, functional rotation, flexibility, coownership, self-management, stock buybacks, privatization and self-service ('do-it-yourself') are unmistakeable symptoms of the underlying corso-ricorso process. This process may take decades before the system of participative autonomy 'snaps in place' and the ownership-management gap is effectively bridged.

Modern socialism, because it did emerge as a crude and artificial interruption of the natural corso-ricorso process, will have to make such transfer by decree. The ownership of the means of production, appropriated from the private owners and absentee shareholders, has now become concentrated in the hands of nobody, i.e., anonymous and bureaucratic state. This 'non-ownership' has to be transformed into the hands and responsibility of real and direct employees - natural co-participants in the enterprise. Otherwise, no reintegration, self-management, self-coordination or competitive knowledge-based advances will be possible in such system.

There is an interesting and paradoxical (potential) advantage of the failed socialism: should the ricorso stage become recognized and acknowledged (i.e., if socialism itself becomes recognized as only artificial, administrative and still incomplete mezzocorso), then the transition to participative autonomy could be swifter and surer than under capitalism. The problem is that the existing classes or strata and parasitic hierarchies and bureaucracies of socialist state must be isolated from their ineffective and damaging coordinative and planning 'functions': their resistance, as that of all conservative forces, is natural and historically inevitable.

If new levels of productivity, quality and competitiveness are to be achieved in a knowledgebased society, the means of production, in agriculture, industry and services, must be owned directly by those who work with them, manage them and are responsible for them: those who invest their earnings, time, effort and knowledge in them. They cannot be owned by external, superficially interested, short-term absentee holders of symbols of ownership, 'useful gamblers', who invested nothing else but money and can transfer their 'investments' within seconds; nor can they belong to the anonymous 'anybody, everybody and nobody' of the modern socialist state.

In a knowledge-based society, means of production rightly belong to those who contribute their knowledge. And because knowledge is nothing else than coordination of action, also to those who contribute their labor. Profound knowledge can still turn out to be one of the few things that cannot be 'atomized' by specialists (destroying knowledge), and which money can't (effectively) buy.

Knowledge seems to be our (only) way out.

\section{Milan ZELENY \\ Fordham University at Lincoln Center New York, NY 10023, USA}

\section{Sources}

- 'The grand reversal: On the corso and ricorso of human way of life', in: M. Ceruti and E. Laszlo, Eds., Physis/To inhabit the earth (Feltrinelli, Milano, 1987).

- 'Spontaneous social orders', in: The science and praxis of complexity (The United Nations University, Tokyo, 1985) 312-328; in: Foundations of cybernetics and general systems theory, Proceedings of the U.S.A.-U.S.S.R. conference, May 17-19, 1985 (Hemisphere, Washington, DC, 1987); General Systems 11 (1985) 117-131. As 'Les ordres sociaux spontanés', in: Science et pratique de la complexité, Actes du colloque de Montpellier, May 1984, IDATE/UNU (La Documentation Française, Paris, 1986) 357-378.

- 'High technology management', Human Systems Management 6 (1986) 109-120. As 'La gestione a tecnologia superiore e la gestione della tecnologia superiore', in: G. Bocchi and M. Ceruti, Eds., La sfida della complessità (Feltrinelli, Milano, 1985) 401-413.

- 'Management of human systems \& human management of systems', Erhvervs økonomisk Tidsskrift (April 1986) 107-116;

'At the end of the division of labor', Editorial, Human Systems Management 6 (1986) 97-99;

'Management of human system \& human management of systems', in: E. Johnson, Ed., Trends and megatrends in the theory of management (Bratt International, Lund, 1986) $35-44$;

'On human systems management: An emerging paradigm', Human Systems Management 6 (1986) 181-184.

- 'The roots of modern management: Bat'a-system', Editorial, Human Systems Management 6 (1986) 4-7; (in Japanese, transl. Y. Kondo), Standardization and Quality Control 40 (1987) 50-63;

'What is integrated process management?' Human Systems Management 7 (1988) 265-267.

'Management support systems: Towards integrated knowledge management', Human Systems Management 7 (1987) 59-70;

'Bat'a-system of management: Managerial excellence found', Human Systems Management 7 (1988) 213-219. 